\title{
Microgeneration: the installer perspective
}

Article

Accepted Version

Creative Commons: Attribution-Noncommercial-No Derivative Works 4.0

Hanna, R., Leach, M. and Torriti, J. (2018) Microgeneration: the installer perspective. Renewable Energy, 116 (Part A). pp. 458-469. ISSN 0960-1481 doi: https://doi.org/10.1016/j.renene.2017.09.023 Available at https://centaur.reading.ac.uk/73053/

It is advisable to refer to the publisher's version if you intend to cite from the work. See Guidance on citing.

Published version at: http://www.sciencedirect.com/science/article/pii/S0960148117308856

To link to this article DOI: http://dx.doi.org/10.1016/j.renene.2017.09.023

Publisher: Elsevier

All outputs in CentAUR are protected by Intellectual Property Rights law, including copyright law. Copyright and IPR is retained by the creators or other copyright holders. Terms and conditions for use of this material are defined in the End User Agreement.

www.reading.ac.uk/centaur

\section{CentAUR}

Central Archive at the University of Reading

Reading's research outputs online 


\section{Microgeneration: The installer perspective}

\section{Richard Hanna ${ }^{1}$, Matthew Leach ${ }^{2}$, Jacopo Torriti ${ }^{3}$}

\section{Abstract}

This paper presents an exploratory analysis of microgeneration installer businesses in the UK during a period of intense change in the policy environment from 2010 to 2012. The research examines the influence of installer businesses on rates of uptake and standards of installation, and the interplay between business practices and the policy environment. The research developed new detailed datasets through a nationwide survey, to which 388 installers responded, and follow-up interviews with 22 installers. Focusing on solar photovoltaics and air source heat pumps installed in households, the results show the fundamental dependence of installer businesses on government financial incentives and on the quality assurance scheme in operation. Market confidence was compromised by the sharp reduction in the Feed-In Tariff (FIT) for residential solar PV in 2012 and long delays to the equivalent Renewable Heat Incentive for residential installations. Nevertheless, more modest FIT levels have reduced the risk of sub-optimal installations and inappropriate specification of microgeneration systems. The findings underline the need for consistent policy to allow installer businesses and their supply chains to develop and mature, and thus facilitate commercial deployment of microgeneration of high quality, raise its competiveness with incumbent forms of energy supply and contribute to decarbonisation goals.

\section{Keywords}

Microgeneration; subsidies; energy policy; Feed-In Tariff; solar PV; air source heat pumps

\footnotetext{
${ }^{1}$ Imperial College London

2 University of Surrey

${ }^{3}$ University of Reading
} 


\section{Introduction}

Microgeneration is a form of decentralised or distributed energy supply (Allen et al., 2008), where electricity generation does not exceed 50 kilowatts $(\mathrm{kW})$, or the production of heat is no greater than $45 \mathrm{~kW}$ thermal capacity (HMSO, 2004). The UK government has previously identified that the deployment of microgeneration can help to avoid substantial energy losses from centralised power generation, transmission and distribution, reduce greenhouse gas emissions, and increase the diversity and security of energy supply (Department for Business, 2006, Bergman et al., 2009, Greening and Azapagic, 2014).

This paper presents a novel perspective on how the practices of installers can affect the uptake of microgeneration technologies. Very few studies of microgeneration in the academic literature have focused on installers - with many tending to focus on adopters, consumers and technical performance. Demand side barriers to the uptake of residential microgeneration, such as upfront investment, ongoing costs and long payback periods have been well studied, and the profiles of early adopters of microgeneration in homes are well established (e.g. older, more environmentally concerned, educated, professional classes, who can afford to pay installation costs up front) (Caird and Roy, 2010, Faiers and Neame, 2006, Roy et al., 2007, Roy et al., 2008).

However, there is a lack of research on how installers of microgeneration influence drivers and barriers to the uptake of microgeneration. A limited number of studies have considered different aspects of the microgeneration supply chain. Previous academic studies have characterised the microgeneration installer industry as a very small, emerging and unskilled market focused mainly on solar thermal installations (Bergman 
and Jardine, 2009, Bergman and Eyre, 2011); this paper re-examines these in the light of the growth and maturation of the market since 2010 .

A particular policy challenge is overcoming barriers to the uptake of residential microgeneration and expanding its deployment beyond early, niche markets (Candelise et al., 2010, DECC, 2011b). The research presented in this paper considers data on microgeneration installations and installer businesses which were collected during a key period of market expansion and contraction from April 2010 to September 2012. This period of study was selected to coincide with the introduction of the UK Feed-In Tariff (FIT)on $1^{\text {st }}$ April 2010. The FIT was set up to incentivise the uptake of microgeneration technologies, including solar photovoltaics (solar PV), by paying set, premium rates for the electricity that they generate and export (Ofgem, 2015). Under the FIT, there was a rapid growth in solar PV installations, particularly during the first two years of the scheme when tariffs for solar PV were at their highest levels, In 2007, the number of microgeneration installations in the UK was estimated at less than $100,000^{4}$ (Energy, 2008), but this mark has since been exceeded with over 730,000 systems, $88 \%$ of which are solar PV, installed by suppliers registered with the Government's Microgeneration Certification Scheme (MCS) from 2009 to 2014 (MCS, 2015c). Market confidence in the heat pump sector was also affected during this period, as the Renewable Heat Incentive $(\mathrm{RHI})$ for residential installations was delayed on several occasions after initially being scheduled to begin in 2011 , until its eventual introduction in 2014 (Connor et al., 2015).

\footnotetext{
${ }^{4}$ The Low Carbon Buildings Programme provided grants for the installation of residential microgeneration between 2006 and 2011: 16,000 household and 3,200 community microgeneration systems were fitted, mainly solar thermal and PV, but also heat pumps, wind turbines and biomass boilers (DECC, 2012).
} 
Towards the end of the study period, considerable uncertainty was created in the solar PV installer market by the reduction of the FIT for residential solar PV from $43 p$ / kilowatt hour (KWh) to 21p / KWh for domestic retrofits from April 2012 (Balcombe et al., 2014, Cherrington et al., 2013). The FIT levels were further reduced since then, following a stated degression linked to the market price for PV installations (Nolden, 2015) and seeking to maintain consistent investment returns. More recently, the government reduced the residential solar PV tariff from $12.5 p$ to $4.4 p$ per $\mathrm{KWh}^{5}$ with effect from April 2016, substantially reducing the investment returns and risking undermining market confidence further, as well as impacting on solar PV deployment rates and employment supported by the FIT (DECC, 2015b, DECC, 2015a).

A number of studies have documented public and customer concerns over low quality microgeneration installations (Balcombe et al., 2014, Connor et al., 2015, Simpson and Clifton, 2014), and a lack of trust of installers amongst consumers (Bergman and Eyre, 2011, Caird et al., 2008, Keirstead, 2007), which may feed back to reduced uptake. Microgeneration technologies need to be fitted by an installer registered to the MCS in order to receive the UK FIT. The MCS implements a programme of annual inspections for installers and sets out installation standards for different microgeneration technologies (MCS, 2015a, MCS, 2015b). The extent to which MCS standards and inspections are effective in upholding standards is uncertain, since the actual performance of microgenerators in households is known to have been undermined by poor or incorrect installation (EST, 2010, Miara et al., 2011). Bergman and Jardine (2009) observed that under a previous Government programme (the Low Carbon Buildings Programme [LCBP]), installers often fitted only one type of microgeneration and their interest was to maximise sales of that technology (see also Bergman and

\footnotetext{
5 The new tariff applies to all solar PV installations of $10 \mathrm{~kW}$ and below, whereas from October to December 2015, the 12.5p / kWh tariff applied to installations of up to $4 \mathrm{~kW}$ (DECC, 2015b).
} 
Eyre, 2011), as opposed to taking a whole house perspective in specifying optimal energy saving solutions.

\subsection{Aim and scope}

This paper presents an exploratory analysis of UK microgeneration installer businesses which aims to understand how they influenced microgeneration uptake by households, both in terms of the rate of uptake (Research objective 1), and the quality of microgeneration installations (Research objective 2), over the period from April 2010 to September 2012. The focus on rates of uptake and installation standards is an approach which is consistent with technological innovation theory relating to the cumulative adoption of innovations (Schilling and Esmundo, 2009, Wilson and Grubler, 2014). In this study, the rate of installation reflects the cumulative uptake of a technology over time, while installation standards may affect technological performance, with implications for the progress of an innovation's diffusion from market introduction towards wider commercialisation.

The findings of this paper have been developed from successive surveys of microgeneration installers in the UK and follow-up interviews, which represents an original methodological contribution. There is a lack of academically rigorous, nationwide surveys of microgeneration installers, at least not for the period of study in the UK which we note is a key period of market change. A recent exception is the Department of Energy and Climate Change's survey of microgeneration heat installers published as part of an evaluation of the Renewable Heat Incentive (DECC, 2016). However, this was a government-commissioned survey relating specifically to the effectiveness of the RHI since 2014.

The research study upon which this paper is based (Hanna, 2014) considered a variety of microgeneration technologies, including air source heat pumps (ASHPs), biomass, ground source heat pumps, solar PV and solar thermal. However, this paper 
addresses the research objectives in relation to solar PV and ASHPs, since these have been the two most commonly installed microgeneration technologies in recent years. For example, from 2009 to 2014, 645,200 solar PV systems were installed, compared with 33,800 ASHPs (MCS, 2016). The research applies principally to microgeneration which is retrofitted to existing homes, because retrofitted systems comprise the majority of microgeneration installations registered for the $\mathrm{FIT}^{6}$.

2. Material and methodsThe data collection comprised two surveys of microgeneration installers, supported by semi-structured interviews. The surveys of microgeneration installers used an online web survey platform: Smart Survey (SmartSurvey, 2015). The questionnaire was optimized following a pilot survey emailed to 235 installers registered to the MCS during 2011, eliciting responses from 71 installers. The surveys enabled basic exploratory questions to be addressed about the nature of installer businesses and included questions to extract information on rates of microgeneration installation in

${ }^{6}$ From April 2010 to March 2014, over 98\% of solar PV FIT installations equal to or less than 4 kilowatt peak (kWp) capacity were retrofitted to households (Ofgem, 2014). 
Table 1 Question areas in main survey and semi-structured interviews

Purpose / research
objective
Installer
businesses and
market entry
(Contextual
relevance to
research
objectives 1 and 2)

Research objective
1:
Impact of installer
businesses on rate
of microgeneration
uptake in homes

Installer business age; year

business first started

installing microgeneration;

previous industry of business

if applicable; previous

experience of respondents;

business ownership and

founding of business;

number of employees and

proportion working on

microgeneration; job title and

responsibilities.

Location(s) of business by region; building types of installations including nonresidential; region of installations for each technology; number of systems installed by technology; frequency and relative success of marketing activities; frequency of payment options offered to customers.

Most common manufacturers and products installed by technology; preferred external training providers; extent of sub-contracting of site survey, design, installation and maintenance; duration of installer and manufacturer warranties, guarantees and maintenance contracts.

\section{Interview question areas}

Reasons for setting up the business; ease or difficulty of market entry (Microgeneration Certification Scheme); how responsibilities were split between staff and extent of sub-contracting.

What technologies companies installed, where they fitted systems (i.e. locally, regionally or nationally), and why they made those choices; marketing activities and factors which influenced and constrained the number of residential systems they could install over a given period of time; how their business was affected by reductions in the UK FIT and delays to the Renewable Heat Incentive (RHI) domestic scheme.

Choice of manufacturers and training providers; warranties and guarantees provided and offered; what installers do to ensure sufficient standards, for example by how they carry out site surveys and specify systems for installations, or manage sub-contractors; why interviewees chose a particular certification body and what their experiences of annual inspections under the Microgeneration

Certification Scheme have been.

homes and proxy data for installation standards. The semi-structured interviews aimed to deepen understanding of key themes emerging from the surveys. The surveys and interviews were structured according to the question areas set out in Table 1, which also governed the coding of interview transcripts. 
The main survey was emailed to over 2,000 installers registered to the $\mathrm{MCS}^{7}$ in 2011 (Figure 1).. The 317 installers who responded to the main survey were asked if they would be amenable to an additional semi-structured interview. In total, 22 businesses were interviewed, either face-to-face or by telephone, during 2012. The 366 installers who responded to the main and pilot surveys (omitting interviewed respondents) were also surveyed again a year later, to evaluate market change in 2012 compared to 2011. This 'repeat survey' was completed by 114 respondents (Hanna, 2014). The primary data collection was supported by secondary analysis of publically available datasets pertaining to microgeneration installation numbers and installers joining and leaving the Microgeneration Certification Scheme (Ofgem, 2014, MCS, 2015a).

In terms of representativeness, the main survey sample of installers was at least 10 per cent of the total number of installer companies accredited through the MCS in 2011. However, the response rate of $16 \%$ to the main survey means there is considerable potential non-response bias. In addition, the timing of the different surveys and the interviews is a factor which has demanded care in the analysis, since the data was collected against a backdrop of a rapidly changing microgeneration market. Figure 1 illustrates how the pilot survey was optimised during a period of peak FIT rates and rapid growth in solar PV installations. The main survey collected data on the microgeneration installer market shortly towards the end of this market growth phase, while the repeat survey collected data at a time when installations were in sharp decline after the halving of the solar PV FITs. The paper also drew upon interviews,

\footnotetext{
${ }^{7}$ According to MCS statistics, there were 2,996 MCS installers in July 2011 and 3,262 installers in August 2011. However, this total is likely to be an overestimate as already-registered installers which became certified for a new technology have been double-counted (MCS, 2014).
} 
which were mainly conducted with main survey respondents over several months prior to the repeat survey, but also under conditions of lower FIT rates.

Figure 1 Timing of surveys and interviews with respect to Feed-In Tariff rates and solar PV installations

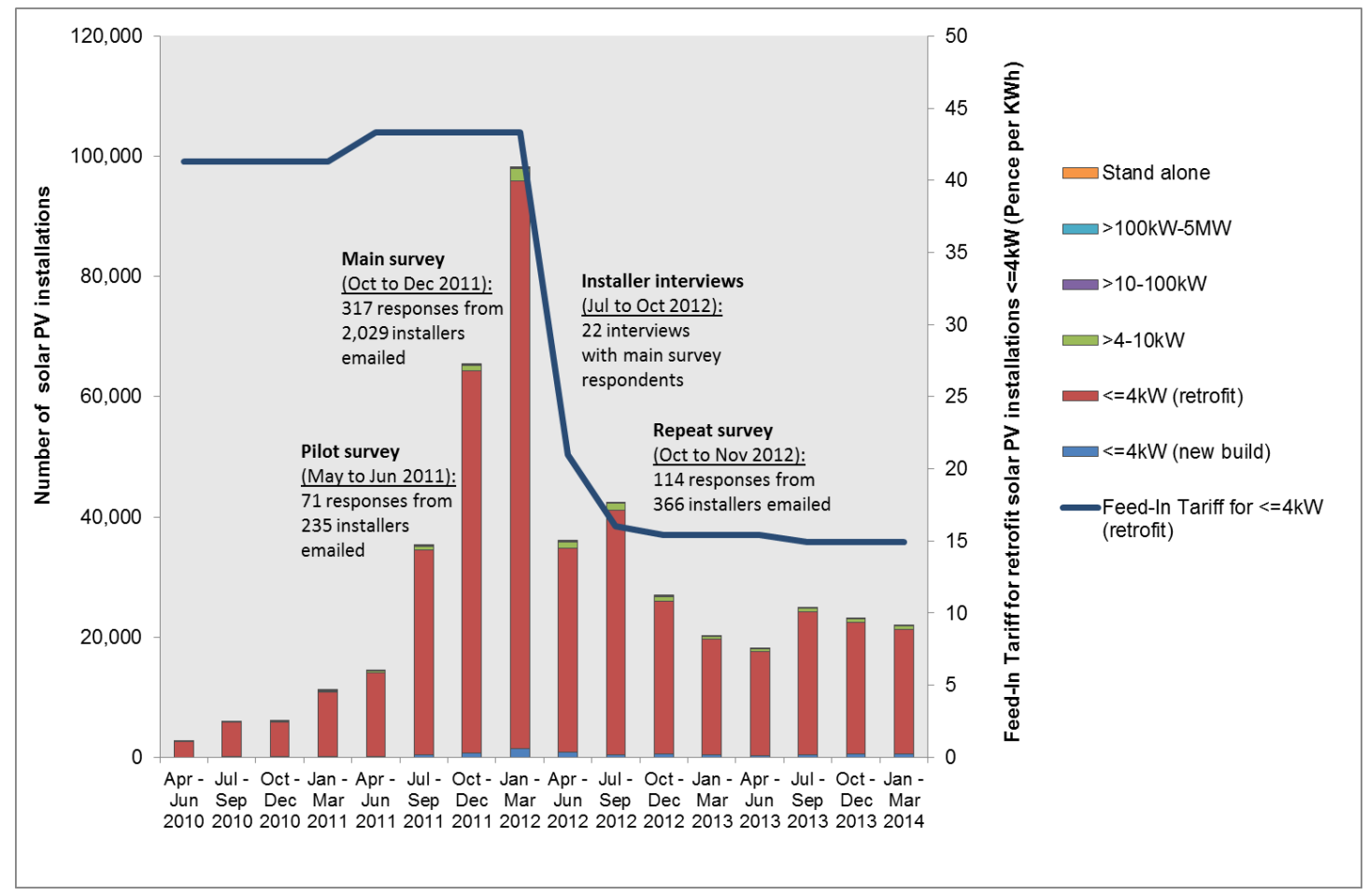

The semi-structured interview methodology allowed a set series of questions to be prepared for each installer, but also permitted flexibility to pick up on themes introduced by installers themselves. The following section of this paper sets out detailed results from the surveys with reference to related interview findings: a more comprehensive analysis of interview transcripts is available in Hanna (2014).3.

\section{Results and discussion}

\subsection{Introduction}

In considering the role of installers, it is first necessary to determine the extent to which the rate of solar PV and ASHP installation is associated with the availability and changing levels of relevant financial incentives, namely the FITs and the $\mathrm{RHI}$ (section 3.2). The FIT introduced by the UK government in April 2010 and the RHI were part of innovation policy, intended to boost learning and experience in microgeneration niche 
markets, where favourable tariffs support technologies whose costs would otherwise prevent them being selected by the general market (Foxon, 2008, Foxon, 2010). The subsequent sections evaluate a range of survey variables and interview data which provide insight on the impact of installer businesses on rates of microgeneration uptake (section 3.3) and installation standards (section 3.4).

\subsection{Financial incentives and changing policy support for the microgeneration installation sector}

It has been argued that FITs are the quickest and most cost-effective way of deploying renewable energy, because they create medium-term certainty for investors, lower capital costs and increased market confidence (Candelise et al., 2010). Official installation statistics (Ofgem, 2014) suggest that the UK FIT was effective in accelerating the rate of solar PV uptake, and also that the sudden FIT reduction implemented in April 2012 stimulated a rush of installation activity beforehand and reduced installation rates subsequently. While the FIT for retrofitted solar PV was at its peak from April 2010 to March 2012, the rate of installation grew exponentially from 2,600 installations in the first quarter of the scheme to almost 94,500 solar PV systems in the last quarter before the FIT was halved in April 2012. From this time until the beginning of 2014 , the number of retrofit solar PV installations stabilised at approximately 20,000 per quarter (Ofgem, 2014).

Similarly, the number of microgeneration installers joining and leaving the FIT quality assurance scheme would seem to be strongly associated with the halving of the residential PV tariff in April 2012. This is indicated by the cumulative number of companies registered to the MCS, which grew from approximately 230 in 2009 to 4,000 in 2011 and 2012, before declining to 3,100 in 2013 (MCS, 2014). With respect to solar PV (Figure 1)(a), while over 2,800 PV installers joined the MCS and 85 left the scheme 
in 2011, the number of businesses joining and leaving the scheme in 2012 was almost equal (approximately 900 in each case). A further 1,400 installers of PV deregistered in 2013 , compared to just 400 who registered in that year. In terms of monthly rates of business registrations and deregistrations, the absolute peak of solar PV installers joining the MCS was in November 2011, when 528 businesses became accredited for fitting PV through the scheme. This was immediately prior to the Government's initial deadline on 12 December 2011 for the halving of the FIT for residential PV (DECC, 2011a).

Figure 2 Monthly number of solar PV installers joining and leaving the Microgeneration Certification Scheme, January 2010 to April 2014

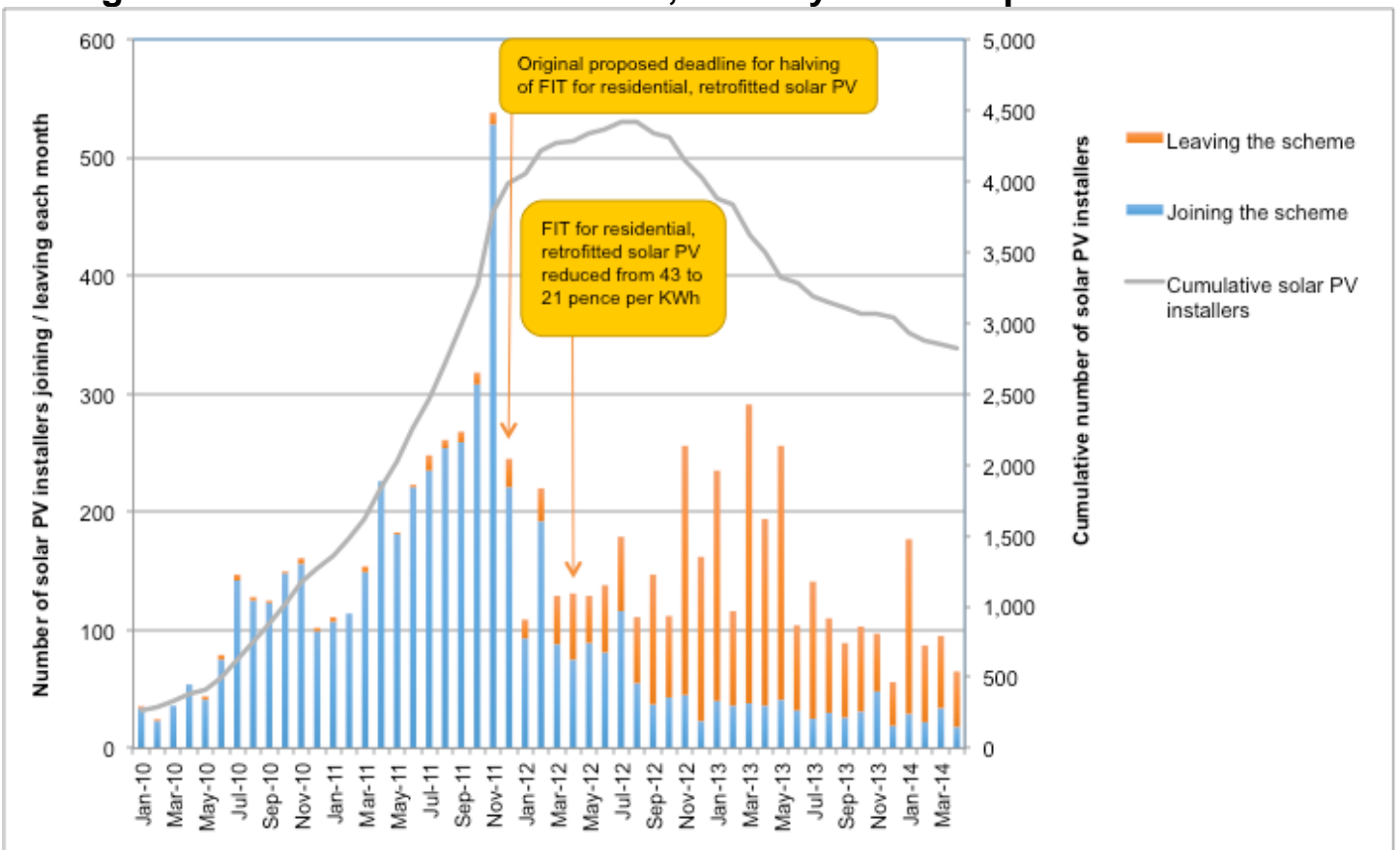

Monthly certifications of air source heat pump installers have been in steady decline since April 2011, down to less than 20 in all months from June 2013 to April 2014 (Figure 1)(b). It is probable that this was due to the decreasing market confidence and uncertainty following unpredictable management of the FIT by the Government, and successive delays to the Renewable Heat Incentive $(\mathrm{RHI})$ residential scheme from 2011 until its introduction in April 2014. As a consequence of these delays, the Government made Renewable Heat Premium Payments available from 2011 to 2014 
to subsidise the installation cost of microgeneration heat technologies, including ASHPs (Connor et al., 2015). 
Figure 3 Monthly number of air source heat pump installers joining and leaving the Microgeneration Certification Scheme, January 2010 to April 2014

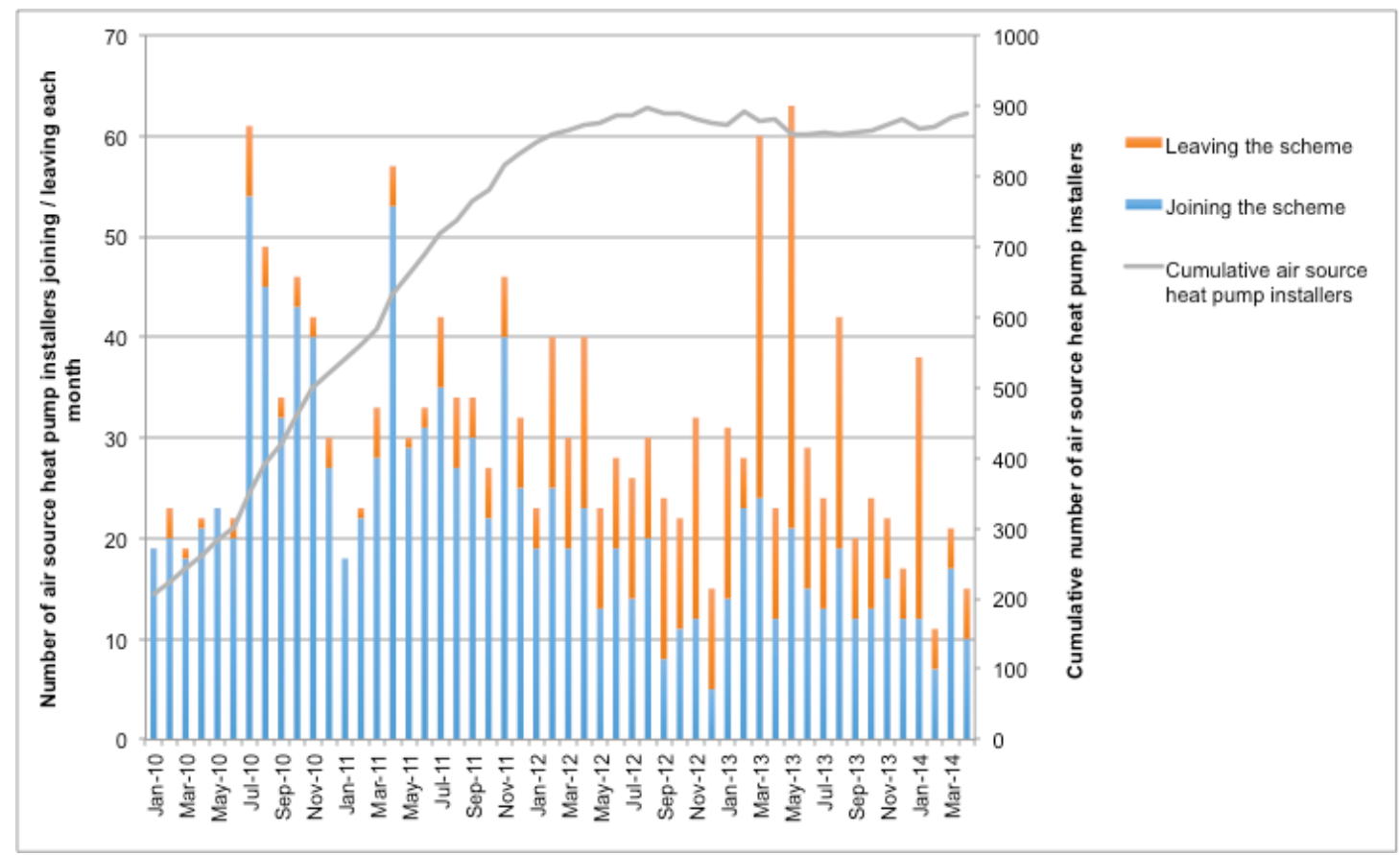

Source: MCS (2014)

\subsection{Installer influence on rates of microgeneration uptake}

[I need to add an intro for Section 3.3 as currently there isn't one. The section launches straight into Section 3.3.1 without any intro text for the section as a whole.]

\subsubsection{Business demographics and extent of installation activity}

Most microgeneration installer businesses surveyed in this study were very small enterprises. Over half of the businesses who responded to the main and repeat surveys had five employees or less, while three quarters had ten employees or less. Business age mirrors size in that half of the 317 main survey respondents were no greater than four years old, with three quarters having installed microgeneration for 
two years or less. Three quarters of respondents to the main survey were founders of their installer business, while only 22 businesses were owned by another company.

Accordingly, as the majority of these microgeneration installers were small and relatively young businesses, most installers who responded to the main survey fitted only a small number of systems. For example, from April 2010 to March 2011, 69\% of 83 businesses who installed ASHPs fitted 1-5 of these systems in homes. $46 \%$ of 186 main survey respondents who installed solar PV fitted 1-5 PV systems on homes over this period, with $25 \%$ installing $6-20$ systems. This compares with just 14 companies fitting over 100 solar PV systems and three businesses installing more than 100 ASHPs over the same period. Overall, these distributions are very similar to those found by (Bergman and Jardine, 2009) for the LCBP from 2006 to 2008: numerous solar PV installers fitted just one system, while only several businesses installed an average of 100 systems each.

\subsubsection{Installer business response to changing policy support and market uncertainty}

The survey findings also suggest that the number of microgeneration systems fitted by installer businesses is dependent on the level and availability of government incentives. For example, from April 2010 to March 2012 at least half of respondents installed more than five solar PV systems per year (Figure 2)(a), whereas the majority of installers surveyed fitted only 1-5 ASHPs a year from April 2010 to September 2012 (Figure 2)(b), which may be associated with a lack of financial support for ASHPs. By comparison, from April to September 2011, the rush to maximise solar PV installations before the halving of the FIT is reflected by the data, with 30 businesses installing more than 60 solar PV systems each. In the year to September 2012, solar PV continued to be the main technology installed in households, with the majority of repeat survey 
respondents (86 from 114) fitting this technology. Nevertheless, the data reveals evidence of declining installation numbers after the halving of the FIT for residential solar PV from April 2012. While 17 respondents installed 1-5 PV systems in the first six-month period measured by the repeat survey (October 2011 to March 2012), this increased to 38 installers who fitted 1-5 PV systems in the following period from April to September 2012. Conversely, 10 respondents installed more than 60 PV systems from October 2011 to March 2012, which declined to one business who installed over 60 units in the subsequent six months. 
Figure 4 Number of microgeneration installations fitted by proportion of responding businesses, April 2010 to September 2012

(a) Solar PV

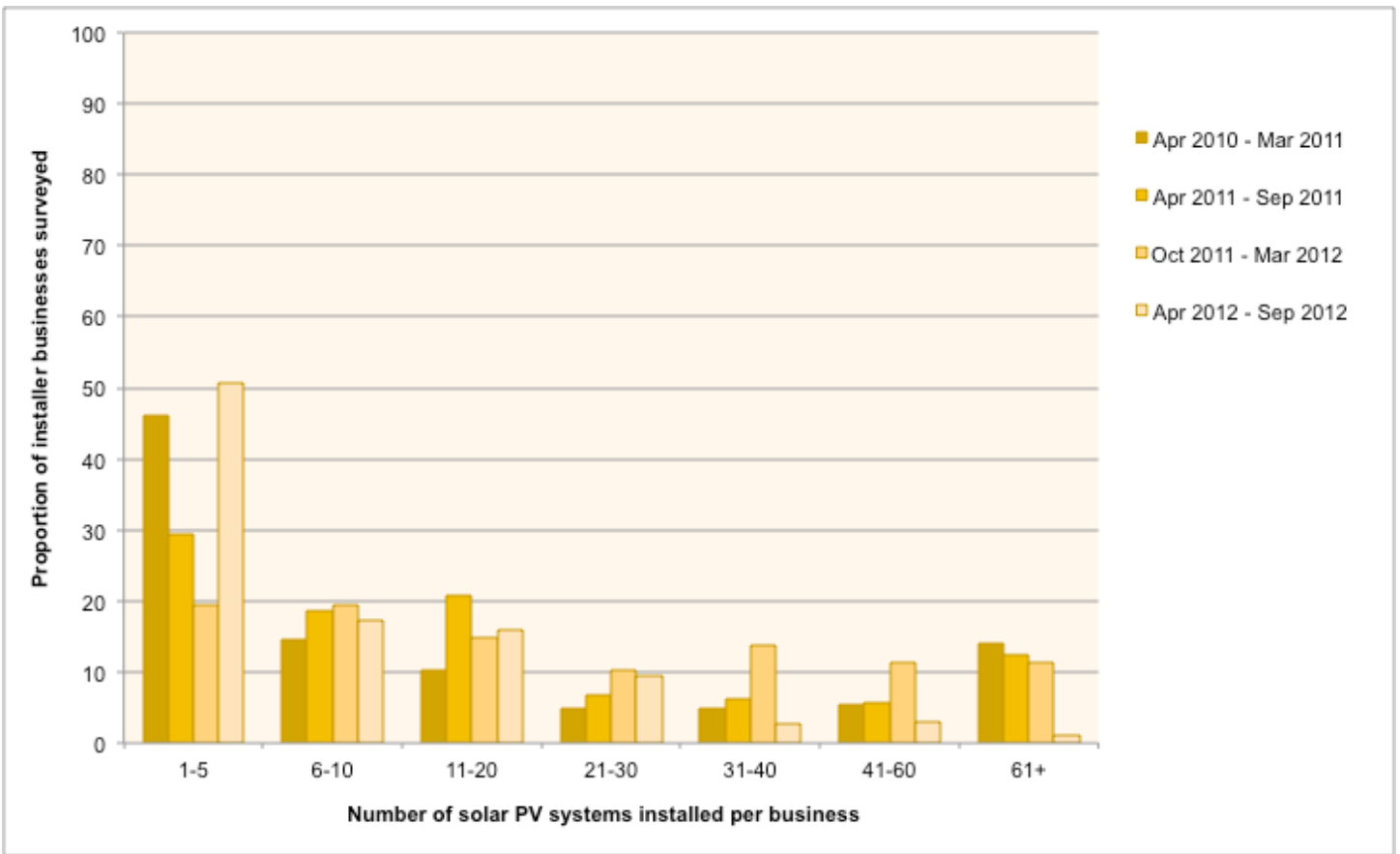

(b) Air source heat pumps

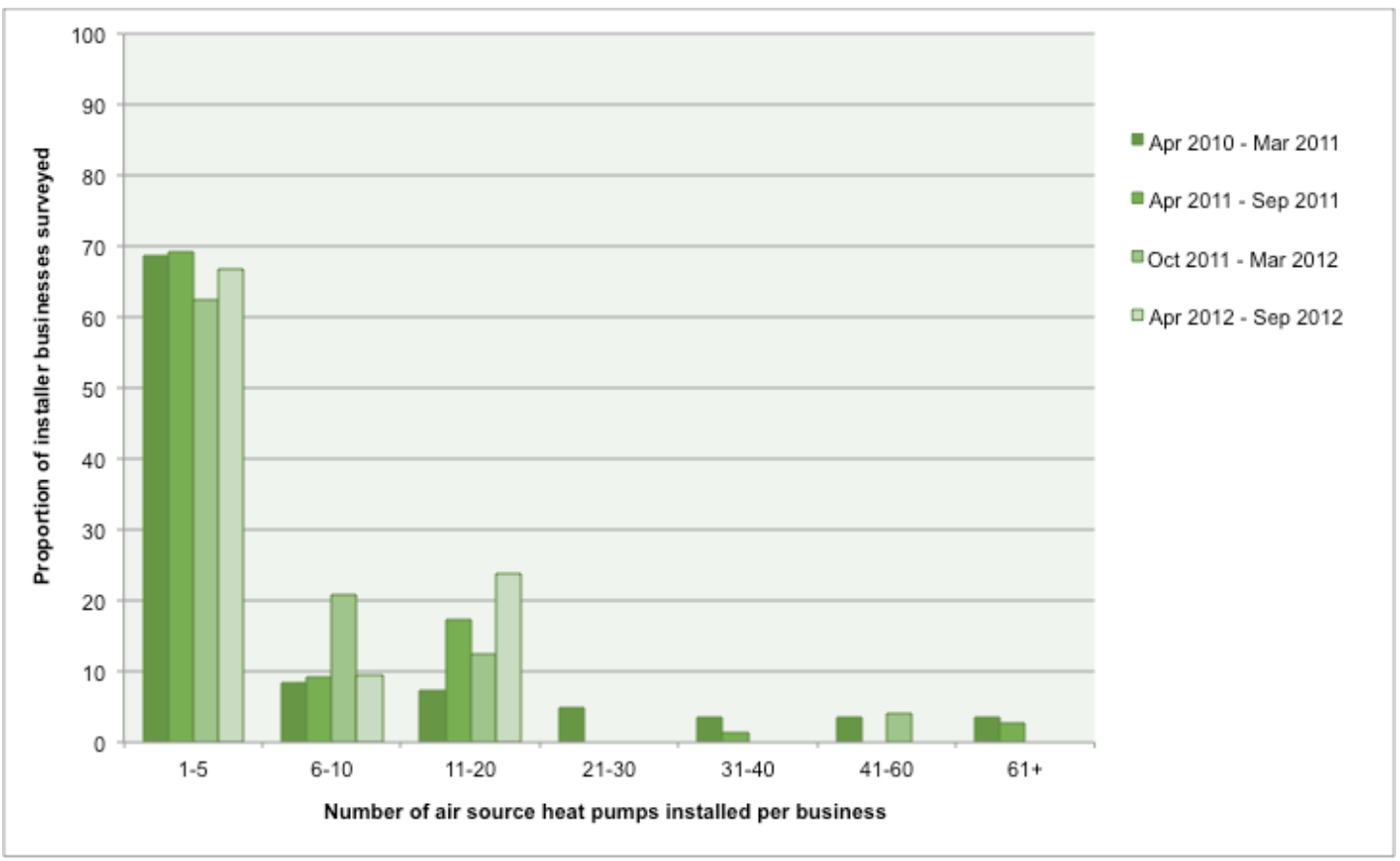


Installers' perceptions of how different factors affected rates at which they installed microgeneration was measured through the repeat survey ${ }^{8}$, as presented in Figure 3. Three quarters of the 114 respondents considered that 'Feed-In Tariff reductions' had led to a 'great decrease' in the number of installations they had fitted in 2012 compared to 2011. The second highest level of adverse impact on installations was attributed to negative media representations of microgeneration (over $60 \%$ indicated that this factor had caused a great or moderate decrease). Around half of all respondents considered that delays to the $\mathrm{RHI}$ residential scheme had caused a great or moderate decrease in their installations over these two years. Conversely, installer marketing efforts and reductions in the up front costs of microgeneration were perceived to be only moderately effective in raising the number of installations. This is despite a considerable fall in costs for solar PV: according to estimates published by DECC for residential-sized systems of less than $4 \mathrm{kWp}$ capacity, costs reduced by $50 \%$ from over $£ 5,000 / \mathrm{kWp}$ in 2009 to approximately $£ 2,500 / \mathrm{kWp}$ in 2012 (DECC, 2013).

\footnotetext{
8 This was based on the question in the repeat survey which asked respondents: 'To what extent do you consider the following factors have increased or decreased the number of microgeneration systems that you have installed in homes in 2012 compared to 2011?' and listed seven potential market change drivers in random order.
} 
Figure 5 Impact of market change factors on number of microgeneration systems installed by businesses in 2012 compared to 2011, shown by cumulative percentage of 114 responses

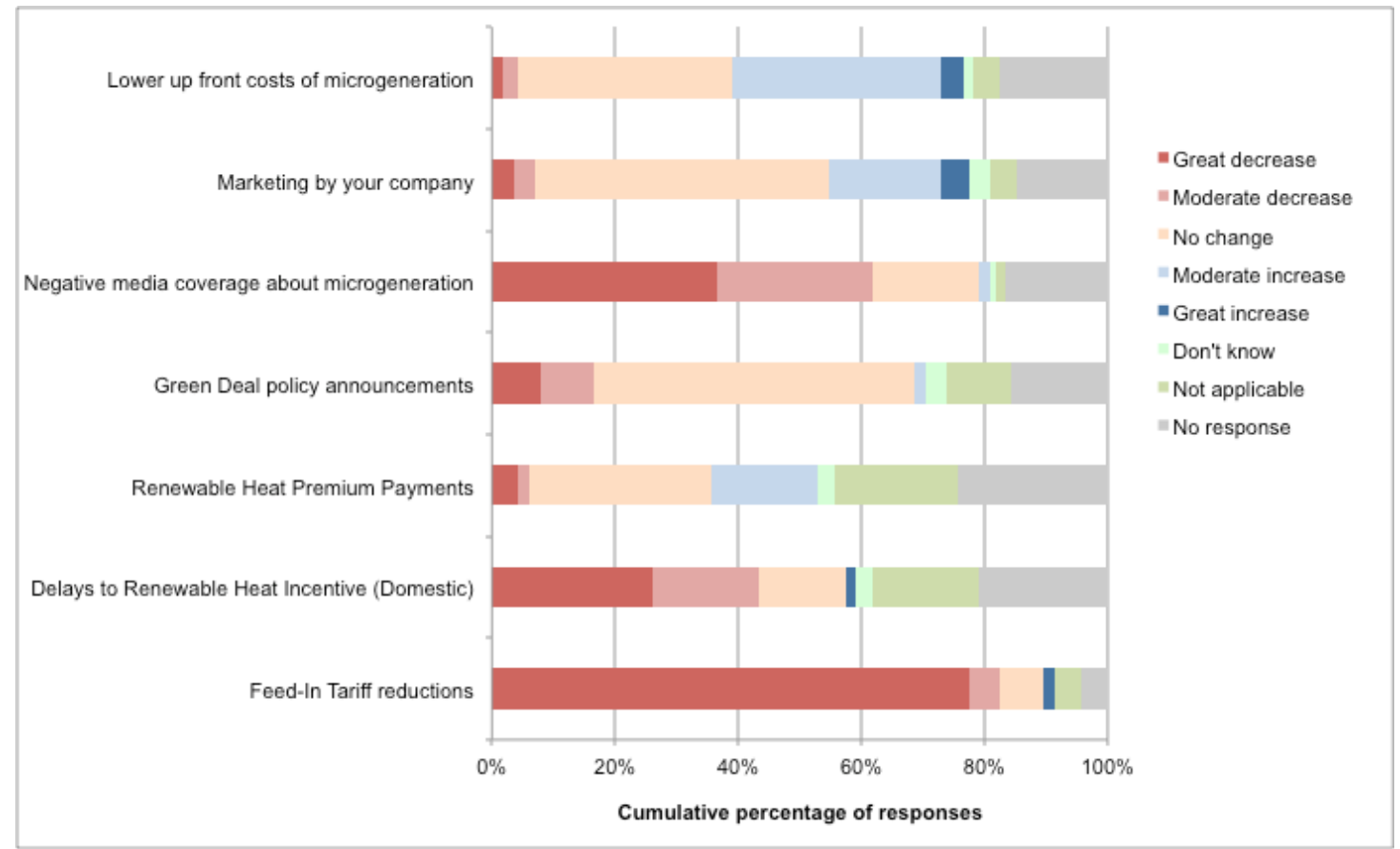

Approximately half of the 102 respondents who commented on market change in the repeat survey remarked on the impact of FIT reductions on their business, particularly in the period from October 2011 to March 2012. FIT reductions were considered to have been managed poorly by government (20 respondents), while 13 installers mentioned delays to the RHI. The onset of market change in 2012 was linked by 13 respondents to public confusion and market uncertainty, as well as to the impact of media coverage (13 installers) - the latter had created the impression amongst potential adopters that they could not get a good return from investing in solar PV, after the halving of the FIT for this technology from 1 April 2012. This negative media representation of small-scale renewables constrained the marketing efforts of installers, according to nine repeat survey respondents. Further to this, as five installers noted, it was very difficult to supply potential consumers with clear information about financial incentives when they were either changing on a regular basis, or there was considerable uncertainty as to when new incentive schemes, such 
as the $\mathrm{RHI}$, would be introduced. This reflected a lack of a co-ordinated strategy by government to deploy microgeneration, and the fragmented nature of financial incentives either in place or proposed to support these technologies (as indicated by four respondents).

A range of adaptations of installer business models had occurred as a result of rapid market change and uncertainty created by unpredictable government policy. At the extreme end of responses to market change, nine repeat survey respondents had either stopped (or were considering no longer) installing microgeneration or were not planning to renew their microgeneration certification licence on its annual expiry. Six respondents had experienced redundancies, reduced the number of their full-time employees, and/or increased out-sourcing of work they had previously carried out in house. While six installers were having to reduce their working hours, or needed to supplement their income elsewhere, other respondents had been able to adapt their businesses structurally to a lower demand market for microgeneration. For example, nine respondents had returned to core services that they had provided prior to installing microgeneration (such as electrical or plumbing and heating contracting). Conversely, six installers had diversified their product and/ or service offerings, while five respondents had moved their focus away from the residential market, in order to fit microgeneration to commercial buildings for example.

\subsubsection{Business location and geographic focus}

Rates of installation are likely to be higher where installers have a greater number of business premises and installed systems over larger geographic areas. However, the majority of microgeneration installers surveyed had only one business location, with both surveys indicating that most installers tended to install microgeneration in homes mainly or exclusively within the region (or devolved country) of their principle (or only) 
business location. Of the installers interviewed, this was particularly the case for those businesses which installed microgeneration heat technologies, such as ASHPs, as they required regular servicing. Solar PV was more capable of being installed nationally, due to a less frequent need to service PV systems. Nevertheless, some interviewees only fitted solar PV locally, as exemplified by one installer, based in the South West, who had decided to install PV locally after the inverters twice developed faults in a system he had installed in East England. Similarly, another interviewee considered that there was sufficient demand for solar PV installations in his local city, and that his business would not have the time or capacity to install systems further afield.

\subsubsection{Marketing strategy}

The regional focus combined with the small-scale nature of predominantly new businesses may be associated with marketing strategies which minimized investment of time and financial resources. The most common forms of marketing across the businesses surveyed were word of mouth and use of their company website, followed by lead generation websites (Figure 4a). A recent survey of 300 microgeneration heat installers indicates similarly that recommendations from other customers and web searches are the most typical routes to finding out about installers (DECC, 2016). Two interviewees in our study also described how they used a local magazine and local free paper respectively to complement their basic word of mouth strategy.

In terms of the effectiveness of different marketing strategies, word of mouth and installer websites also resulted in the highest frequency of enquiries (Figure 4b). Respondents most commonly described the frequency of word of mouth and company website marketing as occurring on a daily basis. However, only between a quarter and 
a fifth of these respondents indicated that enquiries were received daily as a result of these two forms of marketing taking place every day.

Over two thirds of respondents to the main survey reported that they never advertised their services on television or radio, over a third of the businesses had not used newspaper advertising, while around a half did not use door drop leaflets. Even for an interviewee with a relatively large installer business comprising 20 employees, TV and radio marketing was perceived to be unaffordable. These results are consistent with low public awareness of microgeneration technologies (NHBC Foundation, 2012; Frontier Economics, 2013). 
Figure 6 Marketing frequency and effectiveness - main survey respondents

(a) Frequency of installer marketing activities

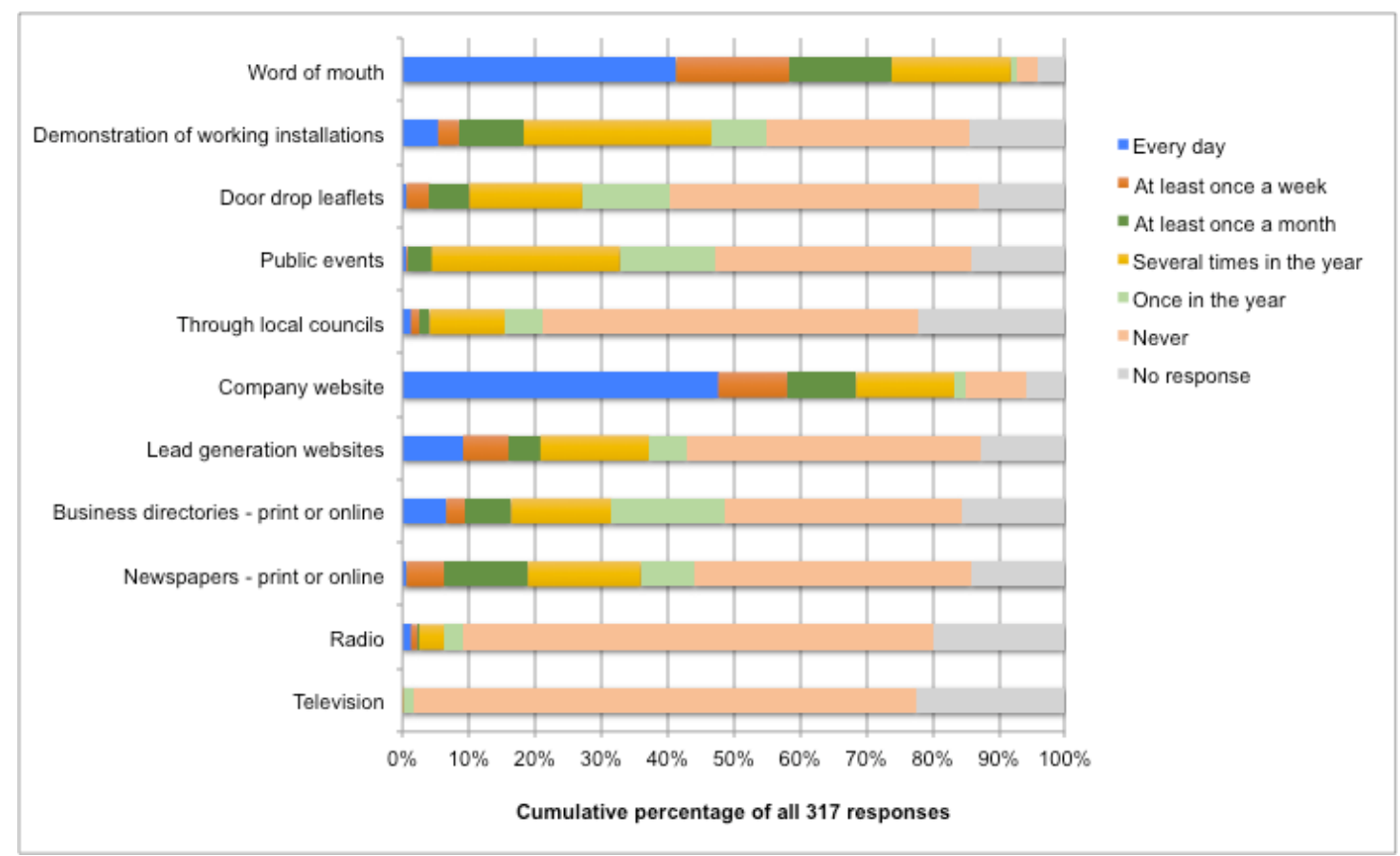

(b) Frequency of enquiries received as a result of installer marketing activities

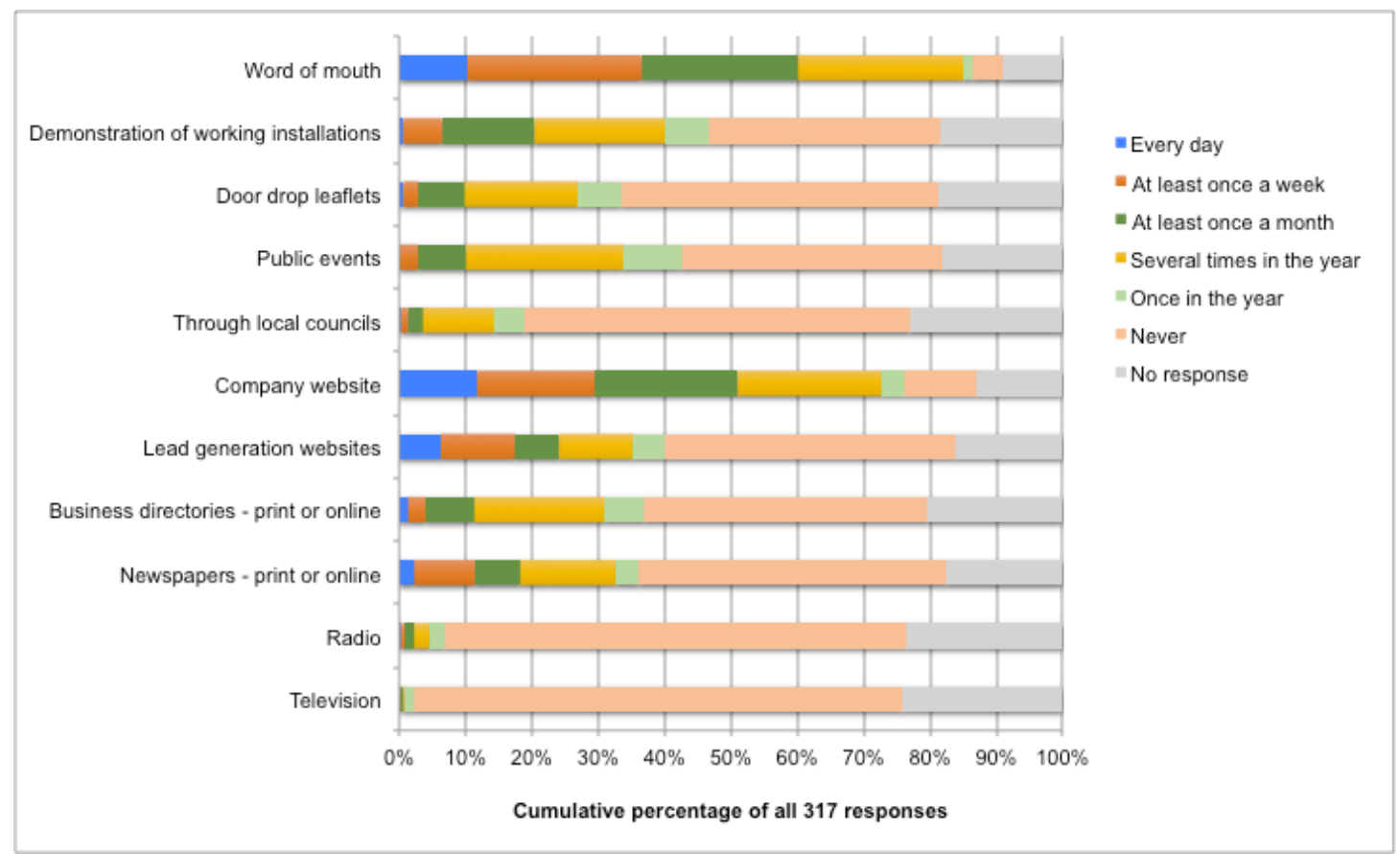

\section{Note to Figure 6}

Lead generation refers to 'the marketing process of stimulating and capturing interest in a product or service' (Marketo, 2016). 


\subsubsection{Business models and retail strategy}

Business models have been proposed either as a means of commercialising innovative technologies, or as components of the innovation process itself (Zott et al., 2011). In this context, Teece (2010) envisages the business model as the link between a company's resources and its market - offering technologies or innovative products to customers based on the way in which a business creates value for those customers. The most commonplace installer business model over the period studied might be described as a form of 'plug and play' (Sauter and Watson, 2007), whereby householders paid for and owned their own microgeneration system, while also being entitled to receive FIT payments for the electricity that it generated. Some of the installers surveyed used solar supply contracting (IEA-RETD, 2013) to rent microgeneration to homeowners for free or at minimal cost, which installation businesses funded by collecting income from the Feed-In Tariffs directly or through a third party.

In relation to the retail strategy of installer businesses, the main survey data indicates that most installers used similar payment methods during the period of study, with the exception of a minority of respondents. For example, customers usually paid a deposit up front for installations, with the remainder paid on completion. The main survey revealed that $80 \%$ of respondents used this method of payment, while $50 \%$ of companies took full payments once installations were completed. Conversely, only 12 businesses provided for payments through mortgage additions, and 16 businesses through low-interest loans. Ten installers offered free installations of solar PV systems, financed by their business receiving the FIT from generation over 25 years, while 18 businesses installed solar PV for free, but financed by a third party receiving the tariff payments. 


\subsection{Installer influence on microgeneration installation standards}

In addition to rates of uptake, this paper also seeks to understand how some aspects microgeneration installation standards were affected by the set up, nature and operation of installer businesses. This section considers the survey and interview data in relation to a number of factors which may have impacted on installation standards during the period of study. These include: installer origins, employee skills and training (3.4.1); choice of manufacturers and products (3.4.2); and the provision of warranties and maintenance contracts (3.4.3). The latter section also addresses an issue of importance which came to light during the interview stage in particular: the effectiveness of the MCS in ensuring that standards were adequate.

\subsubsection{Business origins, employee skills and training}

Many of the employees of the responding installer businesses possessed relevant or transferable skills which could be utilized for microgeneration installation, but they may have lacked specific training on installing microgeneration and integrating systems with existing household heating or electrics. With respect to the previous employment sectors of installers, $44 \%$ of the 317 main survey respondents installed microgeneration from the same year in which they were created. Conversely, $53 \%$ of the responding businesses moved into microgeneration from other sectors, of which $21 \%$ previously traded in electrical and mechanical industries, $11 \%$ in plumbing, heating and gas, and a further $12 \%$ in other aspects of building services (Table 2). At a personal level, respondents had previous employment experience in a very wide range of related and unrelated sectors, with at least half employed in building services or electrical professions, and eight respondents in the environment sector (including sustainability, conservation and landscape design), although a further 13 mentioned renewable energy specifically. In terms of non-microgeneration related sectors, 19 
respondents were previously employed in information communications technology, eight in the automotive sector, and seven in banking and finance.

Table 2 Previous industry categories of main survey businesses

\begin{tabular}{|l|l|l|}
\hline Previous industry code & Frequency & Percentage \\
\hline the year of start-up & 141 & 44.5 \\
\hline $\begin{array}{l}\text { Business always worked in } \\
\text { microgeneration, but delay in setting up }\end{array}$ & 7 & 2.2 \\
\hline Electrical and/or mechanical & 67 & 21.1 \\
\hline Plumbing, heating and/or gas & 34 & 10.7 \\
\hline Plumbing/heating and & 11 & 3.5 \\
\hline electrical/mechanical & & 12.0 \\
\hline Building services (general) & 38 & 2.5 \\
\hline Renewable energy & 8 & .6 \\
\hline Energy (general) & 2 & 100.0 \\
\hline Other & 9 & 317 \\
\hline Total & & \\
\hline
\end{tabular}

The main survey identified a lack of standardization and consistency in training for microgeneration design, installation and maintenance. 216 respondents used 116 different training providers between them, with the most common being NICEIC, a registered charity supporting electrical contractors, and Ecoskies, a training company (Table 3). Manufacturer training was also frequently used by installers. A common perception amongst interviewees was that training providers often had less practical 
experience than installers themselves, and that many manufacturer training courses were introductory or basic courses which a given manufacturer required installers to attend as a condition of purchasing products from them. These findings are consistent with DECC (2011b), who also identified a proliferation of microgeneration training providers, many of which were not based on the National Occupational Standards (NOS) for the performance of individuals in specific employment sectors (DECC, 2011b, UKCES, 2016).

Table 3 The most commonly-mentioned external training providers used by survey respondents

\begin{tabular}{|c|c|c|c|}
\hline Training provider & $\begin{array}{l}\text { Number of } \\
\text { companies } \\
\text { who used } \\
\text { training } \\
\text { provider }\end{array}$ & $\begin{array}{l}\% \text { of all } \\
\text { respondents } \\
\text { to this } \\
\text { question ( } 216 \text { / } \\
317)\end{array}$ & Coding category \\
\hline $\begin{array}{l}\text { NICEIC / PPL } \\
\text { training }\end{array}$ & 52 & 24 & $\begin{array}{l}\text { Industry training } \\
\text { provider }\end{array}$ \\
\hline Ecoskies & 29 & 13 & $\begin{array}{l}\text { Industry training } \\
\text { provider }\end{array}$ \\
\hline Worcester Bosch & 17 & 8 & Manufacturer \\
\hline Mitsubishi & 15 & 7 & Manufacturer \\
\hline CAT & 13 & 6 & $\begin{array}{l}\text { Industry training } \\
\text { provider }\end{array}$ \\
\hline Schuco & 10 & 5 & Manufacturer \\
\hline Daikin & 10 & 5 & Manufacturer \\
\hline
\end{tabular}




\begin{tabular}{|l|l|l|l|}
\hline NAPIT & 9 & 4 & Industry training \\
& & & provider \\
\hline Logic & 8 & 4 & $\begin{array}{l}\text { Industry training } \\
\text { provider }\end{array}$ \\
\hline Grant & 8 & 4 & Manufacturer \\
\hline
\end{tabular}




\subsubsection{Choice of products and manufacturers}

The overall level of installation standards was affected by the wide range of manufacturers used by different microgeneration installers. In the main survey, Sanyo and Sharp were the most common manufacturers of solar PV modules installed, fitted by $38 \%$ of businesses who installed this technology, while a further 55 manufacturers were used between all the installers (Figure 5)(a). Despite the diversity of manufacturers, first generation, crystalline silicon modules have continued to dominate the PV market (Candelise et al., 2013). This pattern of dominant market leaders and numerous, less-frequently used manufacturers was repeated with ASHPs: while 82 installers surveyed used at least 23 different ASHP manufacturers between them, 30 of these installers fitted Mitsubishi systems and 14 used Daikin (Figure 5)(b).

To understand the reasons for the observed distribution of manufacturer choices, the 114 repeat survey participants were asked to rate seven factors according to the extent to which they were a priority when they selected manufacturers for residential microgeneration systems (Figure 6). Product performance and reliability was rated as the most important priority, with $93 \%$ of the 114 respondents indicating that this factor was 'essential' or 'high priority'. Installers perceived the next most important factors to be manufacturer service and back up, terms of manufacturer warranties and wholesale costs of products: the majority of respondents indicated that these were a high priority or essential. Several interviewees used an online database of how solar PV modules and inverters perform in field conditions (Photon International, 2012), in making their decisions on which solar PV systems to purchase. The Photon database was considered by these interviewees to be a more reliable source of information than manufacturer specifications of how modules perform in laboratory conditions.

Figure 7 Manufacturers selected for installations by main survey respondents 
(a) Number of installers selecting Solar PV module manufacturers

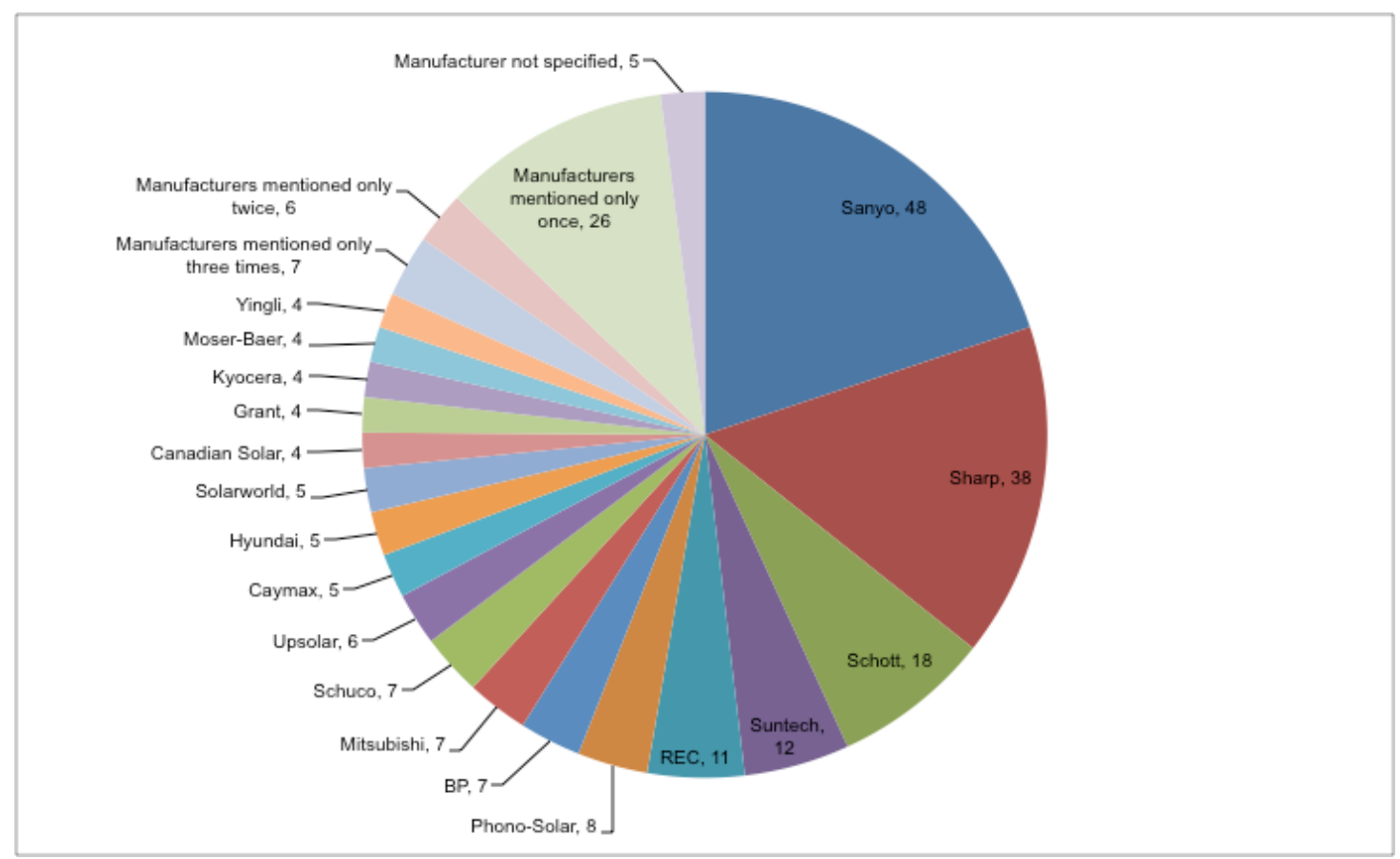

(b) Number of installers selecting ASHP manufacturers

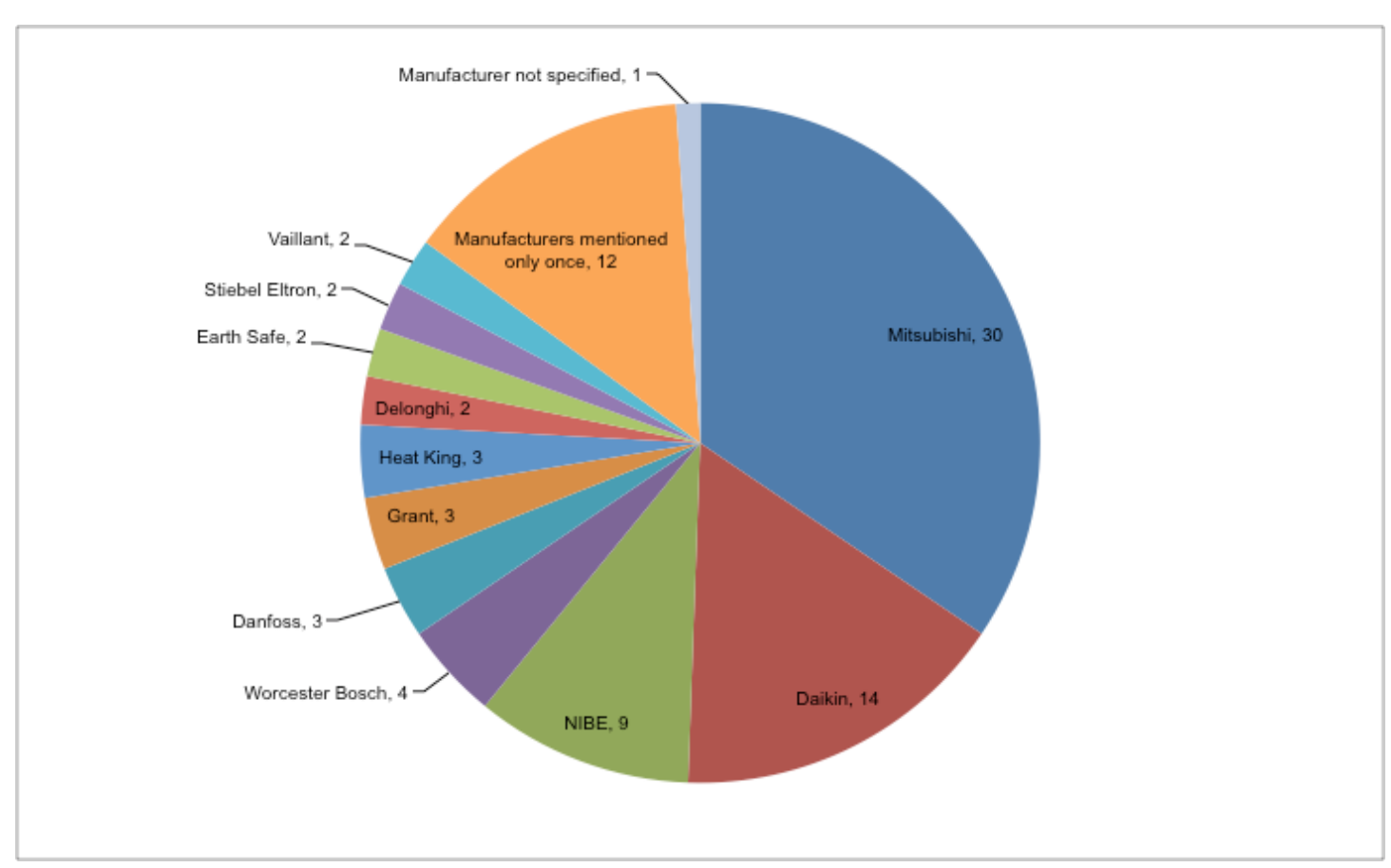


Figure 8 Extent to which repeat survey installers rated seven different factors as a priority when they chose manufacturers for microgeneration systems they installed in homes

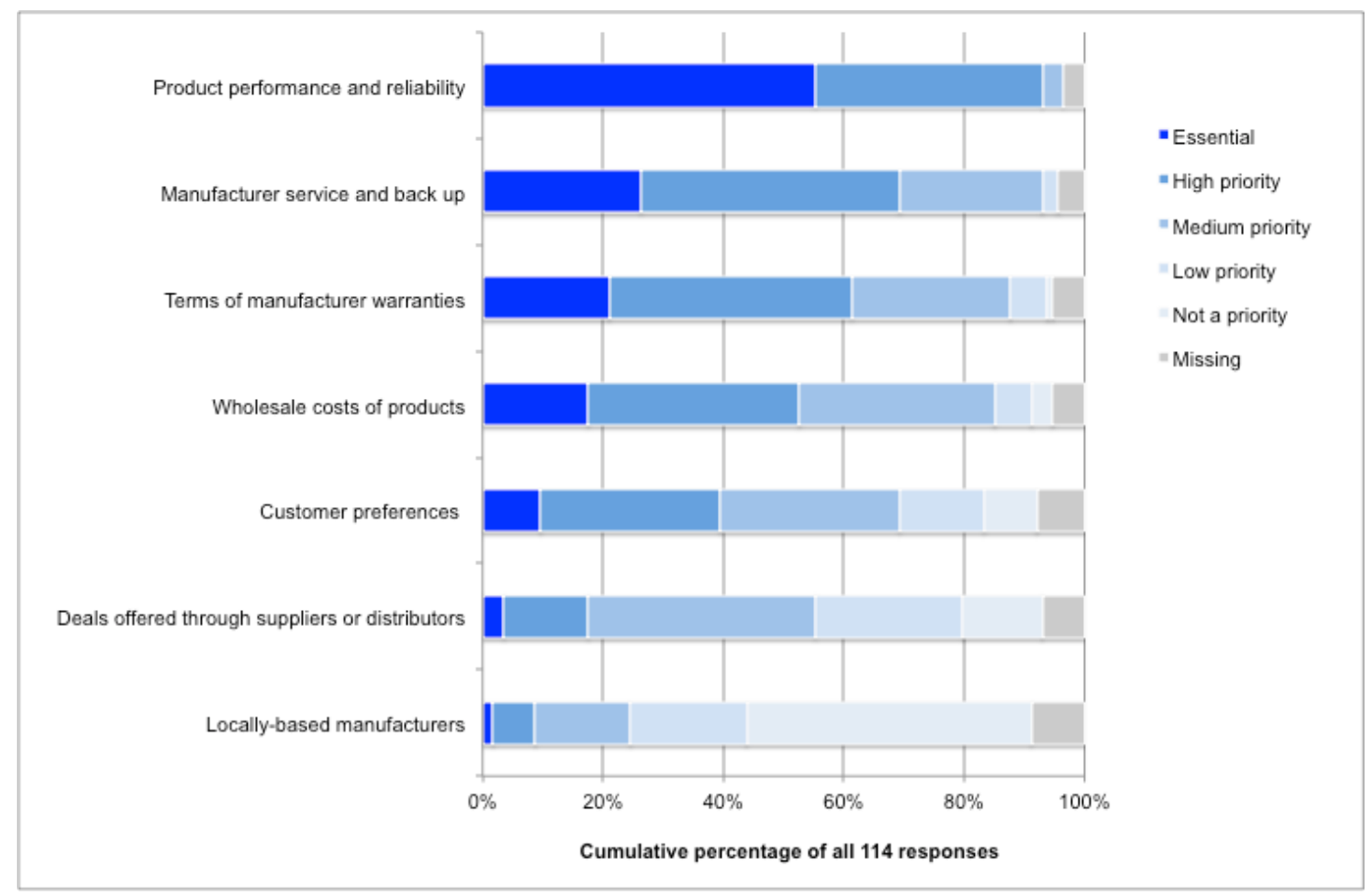

Nevertheless, installation standards may have been compromised due to the management of the residential solar PV market by the government. Several interviewees and repeat survey respondents gave accounts of not being able to buy their preferred products as demand outstripped supply of PV modules and inverters in the rush to the government's proposed deadline to halve the FIT for residential solar PV by 12 December 2011.

\subsubsection{Warranties, maintenance and the Microgeneration Certification Scheme}

The main survey revealed much variability in the extent, type and duration of warranties, guarantees and maintenance contracts provided or offered by installers, with potentially negative implications for the ongoing performance of microgeneration systems which were not covered by such agreements. For ASHPs, product warranties covered by manufacturers were indicated as being of $2-5$ year duration by 21 of 25 
respondents. These were notably longer for solar PV modules, for which 50 of 110 respondents indicated that their product warranties lasted 6-10 years, with 28 installers offering product warranties of 21-25 year duration, and a further 28 respondents warranties lasting 2-5 years. By contrast, the majority of warranties covering faults arising with installation (e.g. 78 of 101 installers for solar PV modules) were for 5 years or less. With respect to extended guarantees or maintenance contracts, at least half of approximately 200 main survey respondents indicated they did not provide these at all.

Moreover, the industry quality assurance scheme, i.e. the MCS (MCS, 2015a) did not operate in a way which effectively safeguarded against systems being installed suboptimally. Under the MCS at the time of the interviews, UK-based installers could register with one of sixteen certification organisations (MCS, 2015a). Minimising the cost of accreditation which varied between the different certification bodies and the cost of training they provided was a common reason for choosing between them. The interviews highlighted issues with the quality of MCS inspections carried out by certification bodies, while inspectors encountered by installers varied in their perceived levels of technical expertise. Most of the interviewees described how annual inspections took place over one working day, focusing on office-based processes and with only a few hours dedicated to visiting an installation. Installers could select installations for the inspectors to visit, which were usually local to their business to save inspectors' time. Furthermore, inspections did not always obtain customer feedback on installations. Together with variable provision and terms of maintenance support, questionable inspection standards increase the risk of poor technological performance post-installation. 


\section{General discussion and conclusions}

The findings in this paper demonstrate how the progress of solar PV into the microgeneration niche market was disrupted by the government's management of the FIT, in such a way that it created a rush of installations to the initial 12 December 2011 deadline, and subsequently to 31 March 2012 ahead of the halving of the residential solar PV FIT. This has been documented elsewhere in the literature (Balcombe et al., 2014, Cherrington et al., 2013) but the present paper reveals the damage inflicted on the underlying installer infrastructure, with long-lasting effects. Similar peaks in solar PV installations, which coincided with subsidy reductions and caused 'boom-bust' cycles in solar industry activity, have been reported in Western Australia (Simpson and Clifton, 2015). Our findings also indicate that during this period, there was a greater risk that standards of installations may have been compromised, through a lack of availability of preferred or appropriate products.

In order to compete with incumbent forms of electricity and heat production, the commercial prospects of emerging microgeneration technologies depend crucially upon the levels, but also the consistency and predictability of policy support for their deployment (Gross \& Watson, 2015). The government introduced a new degression mechanism in August 2012, enabling FIT reductions to be tailored to falling solar PV module costs and faster-than-anticipated rates of deployment (DECC, 2013, Nolden, 2015). While this degression process was clearly timetabled, with tariff reviews at quarterly intervals, it is difficult for installers to market a technology to consumers on the basis of frequently changing incentives (Connor et al., 2015; Simpson \& Clifton, 2015). Moreover, the government's recent reduction of the FIT to $4.4 \mathrm{p}$ per $\mathrm{kWh}$ for solar PV of 10kW and below (DECC, 2015b) was not expected and risks undermining the rate of installation of residential solar PV systems, from some 10,000 installations per month over 2013 / 2014 (Nolden, 2015). 
While householders' financial motivations have been observed to be a key driver for solar PV installation when the FIT for this technology was at its peak (Balcombe et al., 2014), changing policy support for microgeneration means that installers will need to seek alternative propositions for marketing solar PV - potentially on the basis of greater energy self-sufficiency, which could be linked to an additional financial incentive to stimulate the deployment of battery storage technology. In Germany for example, capital grants introduced in 2013 were combined with low interest loans to support the installation of battery storage for solar PV systems (Balcombe et al., 2014, Clean Technica, 2013).

With respect to installers of renewable heat technologies such as ASHPs, the development of supply chains has been undermined by delays to the $\mathrm{RHI}$ and the failure of the RHPP facility to spend all of its budget, which represents a missed opportunity to achieve cost reductions and increase deployment rates (Connor et al., 2015). The secondary analysis of MCS data in this paper charts how certifications of ASHP installers declined from April 2011 to April 2014. Following the introduction of the $\mathrm{RHI}$ for domestic installations in April 2014, a survey of household owner-occupiers identified that the availability of this financial support was in many cases crucial in consumers' decisions to install microgeneration heat technologies (DECC 2016). Notwithstanding the impact and availability of financial incentives, the low uptake of microgeneration heat technologies during the study period was also a consequence of persisting non-financial barriers, due to such factors as inadequate space for thermal stores or perception of inconvenience caused by installation or maintenance (Balcombe et al., 2014, Staffell et al., 2010), or, in the specific case of ASHPs, perceptions of noise, frosting of the external evaporator and aesthetics (Singh et al., 2010). 
Microgeneration installation standards vary according to the wide range of manufacturers and training providers used by different installers. This is again indicative of a niche market where 'learning by interacting' and 'learning by doing' (Foxon, 2008) is still at an early stage of evolution. The main survey suggests that manufacturer warranties for solar PV were longer than for ASHPs, which may reflect more frequent maintenance requirements for heat pumps, and potentially lower manufacturer confidence in ASHPs as a less mature technology compared to solar PV. This may have implications for the ongoing performance of microgeneration heat technologies, if maintenance is discontinued after several years.

The interviews revealed how installers were able to choose which installations were visited by MCS inspectors. Installers also considered that inspections placed too much focus on bureaucratic audits with insufficient time dedicated to installation visits. Taken together, these findings raise serious doubts about the installation quality assurance process, which brings into question the likely long-term performance of some installations. Although the Renewable Energy Consumer Code (RECC, 2016) does require that installers provide their customers with clear information about optional extended guarantees or warranties beyond the mandatory, free-of-charge, manufacturer guarantee, there is a need to educate consumers about the terms of these contracts and whether they are insured, should the installer become insolvent (DECC, 2011b).

The findings from this study have important implications for policy aiming to expand the deployment of low-carbon, microgeneration technologies such as solar PV and heat pumps. A recent review of policies to decarbonise heat supply in buildings in Europe indicates that countries with the most extensive deployment of heat pumps 
(e.g. Sweden and Austria) have successfully combined initiatives that improve installation standards, technical performance and raise consumer confidence through information campaigns and quality assurance (Hanna et al., 2016). Further research could aim to establish an optimal set of policies to stimulate further uptake of microgeneration in the UK, considering the limits and capacity of installers to impact on rates and standards of installation in the current context of low incentives for solar PV, and a continuing low public awareness of heat pumps.

This paper has set out a range of original, exploratory findings on microgeneration installers, which demonstrate how their business activities can have a strong influence on the actual uptake and long-term performance of installed systems. Overall these findings point to the fundamental dependence of installers on the level, availability and predictability of financial incentives. This calls for consistent policy to support the development of a vibrant and sustainable installer base, in turn enabling wider deployment of emerging microgeneration technologies, as they compete with incumbent forms of energy supply and contribute to UK decarbonisation goals.

\section{Acknowledgements}

This research was undertaken for a Ph.D. based at the Centre for Environmental Strategy, University of Surrey, and funded by an EPSRC Doctoral Training Grant / Supergen Flexnet Doctoral Training Award. 


\section{References}

ALLEN, S., HAMMOND, G. \& MCMANUS, M. 2008. Energy analysis and environmental life cycle assessment of a micro-wind turbine Proceedings of the Institute of Mechanical Engineers Part A: J. Power and Energy, 222, 669 684.

BALCOMBE, P., RIGBY, D. \& AZAPAGIC, A. 2014. Investigating the importance of motivations and barriers related to microgeneration uptake in the UK. Applied Energy, 130, 403-418.

BERGMAN, N. \& EYRE, N. 2011. What role for microgeneration in a shift to a low carbon domestic energy sector in the UK? Energy Efficiency, 4, 335-353.

BERGMAN, N., HAWKES, A., BRETT, D. J. L., BAKER, P., BARTON, J., BLANCHARD, R., BRANDON, N. P., INFIELD, D., JARDINE, C., KELLY, N., LEACH, M., MATIAN, M., PEACOCK, A. D., STAFFELL, I., SUDTHARALINGAM, S. \& WOODMAN, B. 2009. UK microgeneration. Part I: policy and behavioural aspects. Proceedings of the ICE - Energy, 162, 22-36.

BERGMAN, N. \& JARDINE, C. 2009. Power from the people: Domestic microgeneration and the Low Carbon Buildings Programme. Oxford: Environmental Change Institute, University of Oxford.

BIS [Department for Business, Innovation and Skills] 2006. Microgeneration Strategy. Available at: http://webarchive.nationalarchives.gov.uk/+/http://www.berr.gov.uk/energy/so urces/sustainable/microgeneration/index.html [Accessed 29 May 2013].

CAIRD, S. \& ROY, R. 2010. Adoption and use of household microgeneration heat technologies. Low Carbon Economy, 1, 61-70.

CAIRD, S., ROY, R. \& HERRING, H. 2008. Improving the energy performance of UK households: results from surveys of consumer adoption and use of low- and zero-carbon technologies. Energy Efficiency, 1, 149-166. 
CANDELISE, C., GROSS, R. \& LEACH, M. 2010. Conditions for photovoltaics deployment in the UK: the role of policy and technical developments. Proceedings of the Institution of Mechanical Engineers, Part A: Journal of Power and Energy, 224, 153-166.

CANDELISE, C., WINSKEL, M. \& GROSS, R. J. K. 2013. The dynamics of solar PV costs and prices as a challenge for technology forecasting. Renewable and Sustainable Energy Reviews, 26, 96-107.

CHERRINGTON, R., GOODSHIP, V., LONGFIELD, A. \& KIRWAN, K. 2013. The feed-in tariff in the UK: A case study focus on domestic photovoltaic systems. Renewable Energy, 50, 421-426.

CLEAN TECHNICA 2013. Germany's energy storage incentive to start May 1. Available at: http://cleantechnica.com/2013/04/17/germanys-energy-storageincentive-to-start-may-1/ [Accessed 13 June 2016].

CONNOR, P. M., XIE, L., LOWES, R., BRITTON, J. \& RICHARDSON, T. 2015. The development of renewable heating policy in the United Kingdom. Renewable Energy, 75, 733-744.

DECC [Department of Energy and Climate Change] 2011a. Feed-in tariffs scheme: consultation on comprehensive review phase 1 - tariffs for solar PV. Available at:

https://www.gov.uk/government/uploads/system/uploads/attachment data/file /42831/3364-fits-scheme-consultation-doc.pdf [Accessed 12 March 2015].

DECC 2011b. Microgeneration strategy. Available at:

https://www.gov.uk/government/uploads/system/uploads/attachment data/file /48114/2015-microgeneration-strategy.pdf [Accessed 29 May 2013].

DECC 2012. Low Carbon Building Programme 2006 - 2011. Final report. Available at: http://www.decc.gov.uk/assets/decc/11/funding-support/fund- 
opportunities/2578-Icb-programme-2006-11-final-report.pdf

[Accessed 30 August 2012].

DECC 2013. UK solar PV strategy part 1: roadmap to a brighter future. Available at: https://www.gov.uk/government/uploads/system/uploads/attachment data/file /249277/UK Solar PV Strategy Part 1 Roadmap to a Brighter Future 08 10.pdf [Accessed 7 July 2014].

DECC 2015a. Periodic review of FITs 2015. Impact assessment. Available at: https://www.gov.uk/government/uploads/system/uploads/attachment data/file /486084/IA - FITs consultation response with Annexes -

FINAL SIGNED.pdf [Accessed 9 June 2016].

DECC 2015b. Review of the feed-in tariffs scheme. Government response. 17 December 2015. Available at:

https://www.gov.uk/government/uploads/system/uploads/attachment data/file 1487300/FITs Review Govt response Final.pdf [Accessed 9 June 2016].

DECC 2016. Census of owner-occupier applicants to the domestic RHI: Waves 1 to

12. A research project commissioned as part of the Renewable Heat Incentive evaluation. Available at:

https://www.gov.uk/government/uploads/system/uploads/attachment data/file 1496390/Domestic census waves 1-12.pdf [Accessed 13 June 2016].

ELEMENT ENERGY 2008. The growth potential for microgeneration in England, Wales and Scotland. Available at:

http://webarchive.nationalarchives.gov.uk/+/http://www.berr.gov.uk/files/file46 003.pdf [Accessed 29 May 2013].

EST 2010. Getting warmer: A field trial of heat pumps. London: Energy Saving Trust.

FAIERS, A. \& NEAME, C. 2006. Consumer attitudes towards domestic solar power systems. Energy Policy, 34, 1797-1806. 
FOXON, T., HAMMOND, G., \& PEARSON, P. 2010. Developing transition pathways for a low carbon electricity system in the UK. Technological Forecasting \& Social Change, 77, 1203-1213.

FOXON, T., HAMMOND, G., \& PEARSON, P. 2008. Transition pathways for a low carbon energy system in the UK: Assessing the compatibility of large-scale and small-scale options. Paper for 7th BIEE Academic Conference. Oxford. FRONTIER ECONOMICS (2013) Pathways to high penetration of heat pumps. Report prepared for the Committee on Climate Change. Available at: https://www.theccc.org.uk/wp-content/uploads/2013/12/Frontier-EconomicsElement-Energy-Pathways-to-high-penetration-of-heat-pumps.pdf [Accessed 13 June 2016].

GREENING, B. \& AZAPAGIC, A. 2014. Domestic solar thermal water heating: A sustainable option for the UK? Renewable Energy, 63, 23-36.

GROSS, R. \& WATSON, J. 2015. Driving innovation through continuity in UK energy policy: Four simple steps to maintain investor confidence, boost innovation and reduce costs in the UK power sector. Working paper. UK Energy Research Centre.

HANNA, R. F. 2014. Installer businesses and renewable energy uptake in homes . Ph.D., University of Surrey.

HMSO [Her Majesty's Stationery Office] 2004. Energy Act 2004, Section 82. Available at: http://www.legislation.gov.uk/ukpga/2004/20/pdfs/ukpga 20040020 en.pdf [Accessed 29 May 2013].

IEA-RETD 2013. Business models for renewable energy in the built environment, Oxon, Routledge.

KEIRSTEAD, J. 2007. Behavioural responses to photovoltaic systems in the UK domestic sector. Energy Policy, 35, 4128-4141. 
MARKETO (2016) Lead generation. Available at:

https://uk.marketo.com/lead-generation/ [Accessed 13 June 2016].

MCS 2014. MCS certified installers report up to 30th April 2014. Available at:

http://www.microgenerationcertification.org/about-us/statistics [Accessed 4 July 2014].

MCS 2015a. The Microgeneration Certification Scheme. Available at:

http://www.microgenerationcertification.org/ [Accessed 19 July 2015].

MCS 2015b. Microgeneration Installation Standard: MCS 001. MCS Contractor

certification scheme requirements Issue 2.5. Available at:

http://www.microgenerationcertification.org/images/MCS 001 Issue $2.5 \mathrm{MC}$

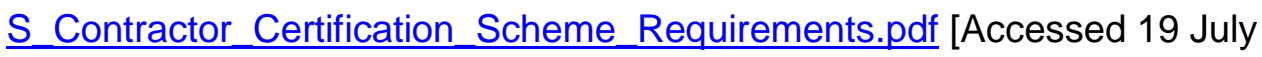
2015].

MCS 2015c. MID statistics report up to 28th February 2015. Available at:

http://www.microgenerationcertification.org/about-us/statistics [Accessed 15 March 2015].

MCS 2016. MID Statistics Report up to 1st March 2016. Available at:

http://www.microgenerationcertification.org/about-us/statistics [Accessed 9 June 2016].

MIARA, M., GUNTHER, D., KRAMER, T., OLTERSDORF, T. \& WAPLER, J. 2011. Heat pump efficiency - Analysis and evaluation of heat pump efficiency in real-life conditions. Freiburg: Fraunhofer Institute for Solar Energy Systems.

NHBC [National House Building Council] FOUNDATION 2012. Today's attitudes to low and zero carbon homes - views of occupiers, house builders and housing associations. Milton Keynes.

NOLDEN, P. 2015. Performance and Impact of the Feed-in Tariff Scheme: Review of Evidence. A Report by Dr Colin Nolden. Science Policy Research Unit, Sussex University, for the Department of Energy and Climate Change. . 
Available at:

https://www.gov.uk/government/uploads/system/uploads/attachment data/file /456181/FIT Evidence Review.pdf [Accessed 27 September 2015].

OFGEM 2014. Monthly central Feed-In Tariff register statistics. Updated 23 April 2014 . Available at: https://www.gov.uk/government/statistical-datasets/monthly-central-feed-in-tariff-register-statistics [Accessed 15 March 2015].

OFGEM 2015. Feed-In Tariff (FIT) scheme. Available at:

https://www.ofgem.gov.uk/environmental-programmes/feed-tariff-fit-scheme [Accessed 12 March 2015].

PHOTON INTERNATIONAL 2012. Photon International - The Solar Power

Magazine. Available at: http://www.photon-international.com/ [Accessed 30 August 2012].

RECC, 2016. Renewable Energy Consumer Code. Available at: https://www.recc.org.uk/ [Accessed 13 June 2016].

ROY, R., CAIRD, S. \& ABELMAN, J. 2008. YIMBY generation - yes in my back yard! UK householders pioneering microgeneration heat. London: Energy Saving Trust.

ROY, R., CAIRD, S. \& POTTER, S. 2007. People centred eco-design: consumer adoption and use of low and zero carbon products and systems. In: MURPHY, J. (ed.) Governing technology for sustainability. London: Earthscan.

SAUTER, R. \& WATSON, J. 2007. Strategies for the deployment of microgeneration: implications for social acceptance. Energy Policy, 35, 2770-2779.

SCHILLING, M. A. \& ESMUNDO, M. 2009. Technology S-curves in renewable energy alternatives: Analysis and implications for industry and government. Energy Policy, 37, 1767-1781. 
SIMPSON, G. \& CLIFTON, J. 2014. Picking winners and policy uncertainty: stakeholder perceptions of Australia's Renewable Energy Target Renewable Energy, 67, 128-135.

SIMPSON, G. \& CLIFTON, J. 2015. The emperor and the cowboys: the role of government policy and industry in the adoption of domestic solar microgeneration systems. Energy Policy, 81, 141-151.

SINGH, H., MUETZE, A. \& EAMES, P. C. 2010. Factors influencing the uptake of heat pump technology by the UK domestic sector. Renewable Energy, 35

SMARTSURVEY 2015. Online survey tool. Available at:

https://www.smartsurvey.co.uk/ [Accessed 19 July 2015].

STAFFELL, I., BAKER, P., BARTON, J. P., BERGMAN, N., BLANCHARD, R., BRANDON, N. P., BRETT, D. J. L., HAWKES, A., INfiELD, D., JARDINE, C. N., KELLY, N., LEACH, M., MATIAN, M., PEACOCK, A. D., SUDTHARALINGAM, S. \& WOODMAN, B. 2010. UK microgeneration. Part II: technology overviews. Proceedings of the ICE - Energy, 163, 143-165.

TEECE, D. J. 2010. Business models, business strategy and innovation. Long Range Planning, 43, 172-194.

UKCES 2016. What are National Occupational Standards? UK Commission for Employment and Skills. Available at: http://nos.ukces.org.uk/Pages/index.aspx [Accessed 9 June 2016].

WILSON, C. \& GRUBLER, A. 2014. Energy technology innovation. In: WILSON, C. \& GRUBLER, A. (eds.) Energy technology innovation: Learning from historical successes and failures. Cambridge, UK: Cambridge University Press.

ZOTT, C., AMIT, R., MASSA, L. (2011) The business model: recent developments and future research. Journal of Management, 37(4), pp. 1019-1042. 
